The workers at the Liverpool School of Tropical Medieine, under the direction of Prof. B. G. Maegraith and Dr. A. R. D. Adams, R.A.M.C. officers at Colchester and Woolwich, and Major-General Covell in India, are studying the effect of paludrine on the relapse-rate of benign tertian malaria, while in Australia a team of research workers in the Australian Army, led by Brigadier N. H. Fairley, is making an intensive study of its prophylactic action. The work of Brigadier Fairley is noteworthy for the great use which is made of volunteers, and the consequent rigorous control which is kept over all aspects of the experiments.

The full significance of all the work, which has been done under the auspices of the Medical Research Council, has still to be assessed, but paludrine appears to be a notable advance in the chemotherapy. of malaria. The Liverpool workers, who were the first to treat human cases with the new substance, are impressed by the latitude allowed the clinician in treatment, for doses fifteen or twenty times the size of those necessary to control clinical symptoms can be given with impunity, while Brigadier Fairley is impressed by the remarkable suppressive action which the drug possesses. Unlike mepacrine, paludrine is not coloured and does not stain the skin. It is also a simpler substance, ehemically, and it should be easier to manufacture. The two qualities, potential cheapness and freedom from undesirable effects at therapeutic doses, are themselves sufficient to make paludrine an important new drug.

\section{Government Support for Research Associations in Britain}

AnNouncing in an address to the Conference of Industrial Research Associations on November 6 that grants to such associations would form a permanent part of the activitios of the Department of Scientific and Industrial Research, Mr. Herbert Morrison, Lord President of the Council, declared that we need research workers to-day as much as in 1940, and that the Government will do everything possible to encourage British industry to use scientifie research. It is essential that some of the money gained to industry by relief from taxation in the new Budget should be invested in research. Large concerns, he hoped, would establish or extend their own research departments, but smaller concerns should give their full support to existing research associations, for no single section of industry can do without this essential scientific partnership and remain virile. Moreover, Government support of industrial research must be backed by readiness to use its results, and firms which cannot maintain fully equipped research staffs of their own should employ at least some trained scientific workers who can co-operate with the appropriate research association and help in the interpretation and application of its work.

Expenditure on research should be regarded as an essential cost, and dealing with the finance of research associations, Mr. Morrison said that with larger incomes the research associations would be able to carry out more of the expensive development work. The Government has therefore decided that in suitable cases it will make single grants to finance capital ex. penditure for such special purposes as buildings and re-equipment, the purchase of particularly expensive apparatus or the provision of semi-scale plant. Until a research association attains an appropriate scale, the present system of a block grant and an additional grant will continue. Eventually, the additional grant will cease, but a new block grant will be made, to continue indefinitely so long as the Department of Scientific and Industrial Research is satisfied with the activities of the association. The associations, Mr. Morrison said, can rely on the Government to proceed as rapidly as possible with the release and training of promising research workers, and all possible assistance will be given for rebuilding or extending laboratories. Sir Edward Appleton, referring to the importance of first-class research workers, pointed out that a monastic life is not stimulating to the young scientific worker, and there should be the closest contact between the research associations themselves, and with the universities and other research establishments.

\section{Air Speed Record by Jet Propelled Aircraft}

Group Captain H. J. Wirson, R.A.F., piloting a Gloster Meteor aircraft powered with two Rolls Derwent gas turbine engines, regained the speed record for Great Britain on November 7, flying over a course in the Thames estuary off Herne Bay. The officially recognized speed, being the average of four flights over the course in opposite directions, was 606.2 miles an hour. Mr. Eric Greenwood, the chief test pilot of the Gloster Aircraft Co., also flew a similar course, on another machine of the same type, averaging 603 miles per hour. The previous speed record was held for Germany by Fritz Wendel. This was set up on April 27, 1939, when he flew a Messerschmidt Bs.109R monoplane at $469 \cdot 2$ miles per hour.

The development of the Gloster machine is the result of research and experiment principally by Air Commodore F. Whittle in conjunction with Messrs. Power Jets, Ltd. The final design and construction of the aircraft and the engine were the responsibility of the Gloster Aircraft Co. and Messrs. Rolls Royce respectively. The attainment of such speeds is due to developments that are perhaps less obvious than the actual result. The production of a gas turbine having a thrust at the jet that gives, at 600 m.p.h., a horse-power of from two to three times greater than anything reached by the conventional aero engine is the most important factor. The use of jet propulsion allows this power to be turned into useful thrust more certainly than the usual airserew method of propulsion could have accomplished. The problems of control of the aircraft at speeds approaching the speed of sound were unique and have been overcome by the aircraft designer. The machine was designed for lower speeds with earlier and less powerful engines, and it is a tribute to his foresight that it has been able to stand up to the increased stresses with a minimum of local strengthening involving no radical redesigning. The actual record-breaking aircraft was a production type of the standard R.A.F. Meteor that is now in service, and has been used in operations both over Germany and for shooting down flying bombs over Great Britain. Special preparation of the machine and the development of the general flying technique for the attempt has been under the supervision of Group Captain Wilson at Manston Aerodrome.

International Council for the Exploration of the Sea

Ar a meeting held in Copenhagen during October 15 -19, attended by delegates and experts from Great Britain, France, Norway, Denmark, Sweden, Finland, Holland and Iceland, the International Council for the Exploration of the Sea was formally reconstituted for a five-year period, as from July 22, 1945. Though 
the last five-year period ended in 1941, the Council was kept in being throughout the War thanks to the efforts of its president, Dr. Johan Hjort, aided by financial contributions from several Continental countries, including substantial additional subsidies from Denmark. At the recent meeting Dr. Hjort (Norway) was re-elected president, and the following four vice-presidents were appointed to constitute, with the president, the Bureau or Executive Committee: Mr. A. T. A. Dobson (Great Britain), Prof. Martin Knudsen (Denmark), Dr. K. A. Andersson (Sweden) and M. Pierre Tissier (France). Dr. H. Blegvad (Denmark) was appointed general secretary in succession to the late Capt. Nellemose, who fell a victim to the Nazis. The scientific work of the Council is organized by a number of area committees, which draw up co-operative programmes of research that are reviewed by the Consultative Committee. The great majority of these committees were re-established at the recent meeting and agreement reached as to the lines of work to be pursued for the ensuing year. Dr. E. S. Russell (Great Britain) was reappointed chairman of the Consultative Committee.

The Council, which was formally founded in 1902 and, through the courtesy of the Danish Government, has its headquarters near Copenhagen, has now survived two wars and has proved itself one of the most successful organizations set up to co-ordinate scientific research on an international basis. It concerns itself primarily with the investigation of fishery problems, together with the cognate problems of marine biology and hydrography. It has published a long series of scientific reports and valuable annual summaries of fishery statistics and hydrographical data. Its journal, suspended during the War, will, it is hoped, reappear early next year. The recent meeting was well attended, especially by Scandinavian members. The British delegates were $\mathrm{Mr}$. A. T. A. Dobson and Mr. J. E. de Watteville, the fisheries secretaries for England and Scotland, respectively, and the British delegation included Sir John Edgell, lately hydrographer to the Navy.

\section{Nicolas Lemery (1645-1715)}

Among the students of medicine and pharmacy who did good work during what has been called "the dawn of scientific chemistry" was the Frenchman Nicolas Lemery, the tercentenary of whose birth falls on November 17. He was born at Rouen, and as a youth he spent some years with Glazer at the Jardin du Roi in Paris, but found his master much imbued with the dreams of the alchemists. Proceeding to the University of Montpelier, he spent three years studying medicine, pharmacy and natural history, and then after travelling through various parts of France took up his residence in Paris. By his lectures he gained a wide reputation which was much enhanced by the publication in $\mathbf{1 6 7 5}$ of his "Cours de Chymie", which in eighty years went through thirteen editions and was translated into Latin, German, Italian, Spanish and English. Scarcely had he sprung into fame than, through being a Calvinist, he found himself threatened by persecution and, like many of his countrymen, fled to England. Embracing Catholicism, however, he was enabled to return to France and resume his lecturing, and in 1699 was elected a member of the Royal Academy of Sciences. Among his other writings were his "Pharmacopée universelle" and his "Traité universel des drogues simple", both published in 1697. "Chemistry," he said, "is a science of observation, it can only be based on what is palpable and demonstrative." Thomas Thomson wrote of him that he was "The first Frenchman who completely stripped chemistry of its mysticism, and presented it to the world in all its native simplicity". Lemery died in Paris on June 19 , 1715, leaving a son, Louis (1677-1743), who held important medical appointments in the French capital and published several books.

\section{Karel Vrba (1845-1922)}

Prominent among men of science in Bohemia towards the end of last century was Karel Vrba. Born at Klatovy in west Bohemia on November 10 , 1845, he studied science at Prague and graduated in 1868, first becoming assistant to the professor of mineralogy, Dr. V. von Zepharovich, and later docent in petrography. Then he was appointed professor of mineralogy at Czernowitz in Bukovina, returning to Prague in the same capacity in 1881 when the Czech University was reinstated. At this time there was a complete overhauling of the old collection of minerals, to which Vrba constantly added more to make it as complete and representative as possible. He gave the first detailed descriptions (sometimes as long monographs) of twenty-nine minerals, mostly occurring locally though a few came from abroad, including one from Bolivia. The accounts of stephanite (1895) and the beryls of Pisek (1888) are regarded as Czech classics in science.

For teaching purposes, Vrba constructed special crystal models that were produced in tens of thousands and were used in all parts of the world, although their origin was not always attributed to him. $\mathrm{H}_{e}$ was prominent in the movement that led to the foundation of the Czech Academy of Science in 1890. Since 1869 there had been a Natural Science Club in Prague, and Vrba attended the lectures and joined in the biological and geological excursions. Nevertheless there was a need for a more august body for the discussion and publication of original researches. The Academy soon became the leading Czech scientific institution. Vrba retired in 1912 and lived through the First World War to see the early years of the Czechoslovak Republic, though he was too infirm to take an active part in the rapid expansion of scientific activities that occurred after 1918. Besides other foreign connexions, he was an honorary member of the Leningrad and Odessa scientific societies.

\section{Announcements}

THE following have been elected honorary members of the Institution of Civil Engineers: Field Marshal the Hon. Sir Harold Alexander and Sir Edward Appleton.

Str Lawrence Bragg is visiting Portugal under the auspices of the British Council to lecture on "Some Problems of the Metallic State" and on matters connected with X-rays. He will lecture in Lisbon, Oporto and probably also Coimbra.

SrR George Stapledon is to retire from the post of director of the Grassland Improvement Station on December 31. Sir George undertook to organize and direct the work of the Station as a war-time task, and now wishes to be relieved of these respon. sibilities.

As exhibition is being arranged at the Curtis Museum, Alton, Hants, during January 11, 12 and 14, 1946, to commemorate the bicentenary of William Curtis (1746-99), founder of Curtis's Botanical Magazine, who was born at Alton. 